\title{
Developing terminology for side facades and side setback areas in Japanese neighborhoods: a study on utility and perception
}

\author{
Amir Shojai", Suguru Mori and Rie Nomura
}

\begin{abstract}
The contribution of front or back yards to sociability has been the subject of several studies. No such finding however is evident for side setback areas, short distances kept between adjacent buildings, which in the case of comparatively dense Japanese urban neighborhood environments can be as short as a few decimeters. The present study locates side setback areas and building facades that look towards them in Japanese planning terminology, and examines them from the residents' point of view. The data for this preliminary step of the research was collected based on a carefully designed and explained 2014 survey of 190 academics scholars throughout Japan. The results suggest that no demographic characteristic or housing type, number of floors or period of time living in the area were shown to be significant in residents' perceptions towards the side setback areas. Those who had no side setback area were more concerned with their privacy, smoke, sound or darkness whereas those with side setback areas were more satisfied. As for preferences, having a Green Wall, Terrace/Balcony and Living/Dining were the preferred choice of those with side setback areas. All respondents tended to perceive the spaces as valued for the light and ventilation they provide. Several activities such as storage, parking and drying clothes were common among the respondents' perceptions of activities suitable for these spaces.
\end{abstract}

\section{Background}

The relationship between architecture and the social/ behavioral sciences is a seemingly cyclical, as well as occasionally conflictual, one (Weisman 2001). Among his ideas to extend architecture from buildings to places and experiences, Weisman proposes to consider using 'attributes' when it comes to experiencing places rather than more traditionally psychological terms or 'modalities', e.g. perception, cognition or behavior. He refers to 'attributes' as those qualities of spaces we attribute to places after our experiences with them, a more tangible concept and expression than the former psychological ways of defining an experience. There are many common sets of attributes across ranges of place types, e.g. accessibility,

${ }^{*}$ Correspondence: amirshojai@frontier.hokudai.ac.jp Graduate School of Engineering, Hokkaido University, North 13, West 8, Kita-ku, Sapporo 060-8628, Japan crowdedness, privacy, comfort, and any significance the place holds for its users, e.g. beauty, attachment etc. He suggests us to take note of patterns, as naturally including functional and experimental programming, to see and decide how to meet people's needs, desires and aspirations in places (Weisman 2001).

Another term which comes across architectural and social/behavioral studies is territory. Habraken states space under control as territorial. Territorial control is the ability to close a space and to restrict entry. The built environment is observed as territorial organization, as spaces under control, thus territory is defined by acts of occupation (Habraken 2000).

Built form can suggest territory, but it is the act of occupation that defines the extent of a territorial claim. The actual territorial boundary is indicated not by the building but by parts and objects; potted plants, door mats, and umbrella stands in front of residents' entries in 
the corridors as examples. Their claim is understood and respected as an identification of territory. The margin created thus softens and articulates the razor-thin line of demarcation offered by architecture (Habraken 2000).

Evans and McCoy (1998) in their taxonomy study researched the possibility of architectural dimensions that may affect human health. They summarized these dimensions as stimulation, e.g. noise, light, crowding etc.; coherence, e.g. organization, exterior vistas etc.; affordance, e.g. ambiguity etc.; control, e.g. boundaries, crowding, privacy etc.; and restoration, e.g. minimal distraction, solitude etc., as a preliminary set of environmental dimensions interrelated to stress, each one consisting of explicit design elements.

In a fully urban environment, building and street are closely tied: the façade forms part of the street wall, and an edge (Lynch 1960) of a domestic territory. Territorial variation on the city blocks configurations vary from front gardens or arcades, to inner private or communal gardens each resulting in different territorial hierarchies and boundaries. Examples vary from inner urban neighborhoods in Europe where houses are formed around city blocks to those in North American urban and suburbs blocks, their difference further articulated by possible location of street wall, fences or steps between house and territorial boundary which is the periphery line. Landscaping in the North American suburb as an example is designed to avoid explicit boundary marks. They are not shaped to extend either house of street. The territorial claim is quite separate from the building. Here, demarcation of territorial boundary is essential to distinguish and preserve the gardens integrity. The lawn is open and unprotected although subtly marked. Each boundary is known and protected by neighbors who share it
(Habraken 2000), whereas in urban blocks in Europe, the territorial boundaries are the buildings themselves.

In describing setbacks configurations as conveying strong meanings of privacy and territorial demarcation, Habraken (2000) mentions Japanese case where placement of elements such as a small tree and some shrubs between the territorial wall of the boundary and the house only two or three feet behind it, to hide groundfloor windows play a stronger role than the dimensions in assigning a territory (Fig. 1).

This research is studying the physical configurations of facades and utilization of side setbacks as the nonbuilt territories and boundaries of residential buildings in Japan. Side setbacks areas here refer to the distance between two neighboring buildings formed after the distances which one or two buildings set back from their boundaries. The Japanese case is studies as it is distinguished from the urban residential zones where buildings are set tight along the street and collectively form a wall to the street whereas in Japan the presence of side setbacks along with the changing location of the buildings inside their plots creates constant changes to the streetscape.

The flammability of wooden buildings combined with high density of dwellings produced a high risk of fire, after two big fires of Tokyo in 1872 and 1923, and also 1932 earthquake lead to the introduction of building laws in 1919 and its revision in 1968 with stipulations of side setback requirements particularly for those low-rise residential areas composed mostly of wooden-frame residences, until now.

Under the current Building Standard Law of Japan, In Japanese urban neighbourhoods, there are minimum side setback area requirements of $1-1.5 \mathrm{~m}$ in two categories
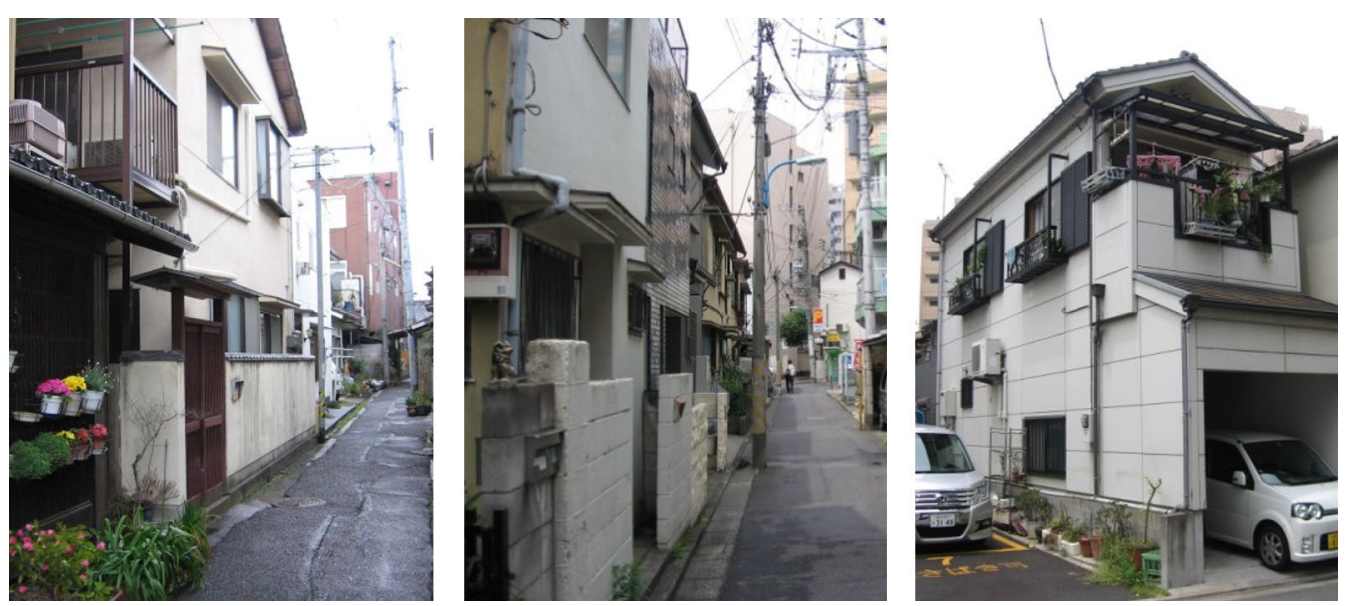

Fig. 1 The demarcation of the territory by a boundary wall (left Kurashiki, middle and right Tokyo) 
of low-rise exclusive residential districts (nine universal categories for planning zoning in Japanese cities, seven of them include residential zonings (Building Standard Law of Japan 2009). In other categories, there are respective setbacks from their boundaries practiced which create a sense of independence. The presence of side setbacks in the course of land scarcity and market prices in cities in Japan suggests these spaces to be fully utilized particularly in the cases of those low-rise houses and apartments abutting them. The street edges are therefore neither visually prominent nor impenetrable. The change in the landscaping indicates a boundary, and marks the territory. Boundary forms hardly include fences to or short part masonry walls. As a result, visual connection and scope to and from the street as well as the neighboring plots are provided.

Side façade configuration varies greatly. In most of the cases there is no change in the façade material of street facades and side facades which indicates the attention to their appearance and maintenance, however these spaces are mostly noted as left-out spaces with very limited to no view and access from the buildings (Fig. 2).

"Clothes-drying spaces refers to a small structure usually constructed of steel bars on top of the projecting first floor roofs, providing enough space only to step outside and hang clothes to dry out under the sun.

\section{Japanese neighborhoods pattern}

In a Japanese neighborhood, blocks show a unique pattern of divisions and sub-divisions, scales of buildings and their layout due to the rather flexible arrangement of buildings and their associated open spaces including back yards and setbacks, resembling a 'kind of patchwork' as Shelton says (Shelton 1999) of buildings and open spaces. The presence of a range of open spaces scattered between the buildings-with their scale and position depending on where the buildings are positioned-free from their neighbors, is a notable feature which is the focus of this study. Physical attributes of the neighborhoods in Japan change constantly owing to the more extensive classifications for residential districts and flexible provisions, namely land coverage ratio and floor area ratio.

In his book on comparing urban scenery between France and Japan, Wada (2007) mentions that the scholars in Japan do not necessarily think of the French example of having the buildings set tight along the street as historically aesthetic value. He mentions the Japanese development as separate buildings slowly built on scattered rice fields one after another and eventually compose the townscape.

Ashihara (1986) calls Japanese city as an Amoeba, referring to the freshwater organism which keeps changing its face. He refers to Japanese city's continuously changing appearance due to replacement of buildings of various types and heights, which he discusses, may look disorderly from outside perspective, but it is what he calls a 'hidden order' which corresponds to the Japanese way of living and thinking.

In his Collection of Essays, Buddhist Priest Kento Yoshida write "A house should be built with the summer in mind... a badly made house is unbearable when it gets hot" (Tsurezuregusa essay no 55 translated by Keene 1981). The Collection of Essays seems to have been written between 1330 and 1332 and is widely considered as one of the gems of medieval Japanese literature.

Houses and small shops lined up next to the road without any space between the houses or between the road and the house and this tradition was carried on into the Edo period (1603-1868). Since frontage on main streets was of prime importance for merchants, the typical pattern of urban housing was blocks of buildings, with the merchants on long narrow lots facing a major thoroughfare, and laborers and the like renting small, usually one-room, apartments in long buildings called Nagaya, which are the Japanese equivalent of tenements which were accessible through the alleyways between the town houses. The merchant houses or Machiya, whether large or small, typically had a shop in the front where trade or business was conducted, with family and employee quarters behind the shop, and the storage area at the rear. In early Edo period, the well-to-do commoners were building minka or commoners' houses which provide evidence for an important historical trend in the rise in the level of wealth and standard of living for the general population (Morse 1972; Hanley 1997; Hirai 1998).

The entrance to some of Tokyo better class houses are at the side. The back of the house and one side, at least, have a verandah, mostly stand back from the street and are surrounded by gardens. In case of common houses, the entrance is usually by means of a large gate used for vehicles and heavy loads, and by the side of this was a smaller gate used by people.

Since the revolution of 1868 there appeared a new style of building in Tokyo generally occupied by poorer classes, in which a continuous row of tenements is under one roof and each tenement has its own separate entrance directly upon the street. In countryside such as Morioka suburbs low-roofed houses each standing with its end to the street. The street is bordered by a high rustic, bamboo fence; and between the houses are little plats filled with bright-colored flowers, and shrubbery clustering within the fences, even sending its sprays into the footpath bordering the road (Morse 1972).

Another function for small alleyways between the Nagaya was the highly effective traditional collection of night soil for use by farmers outside the city (Fig. 3). Because farmers paid well for this fertilizer, management 


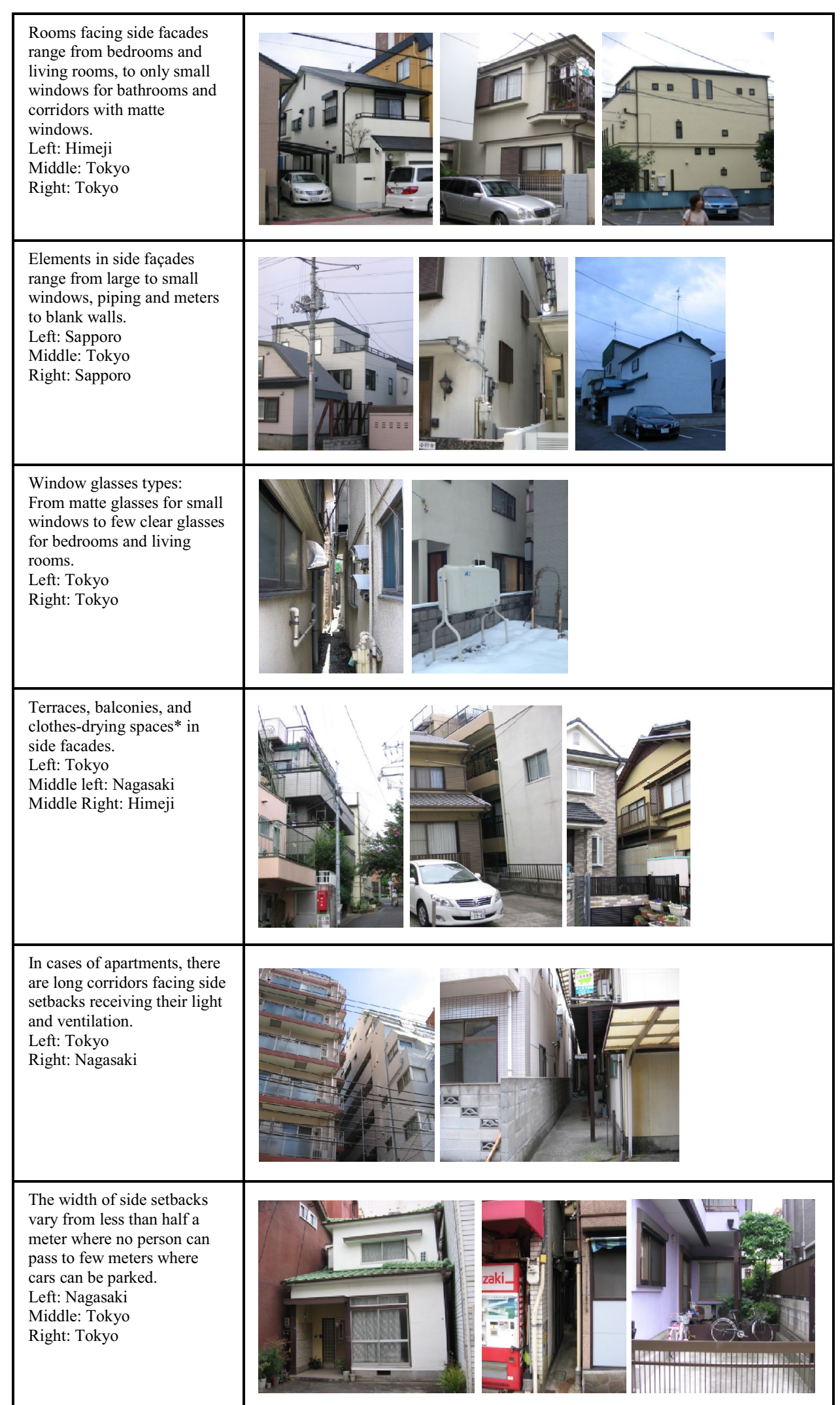

Fig. 2 Physical characteristics of the side setback areas and side facades in Japan 


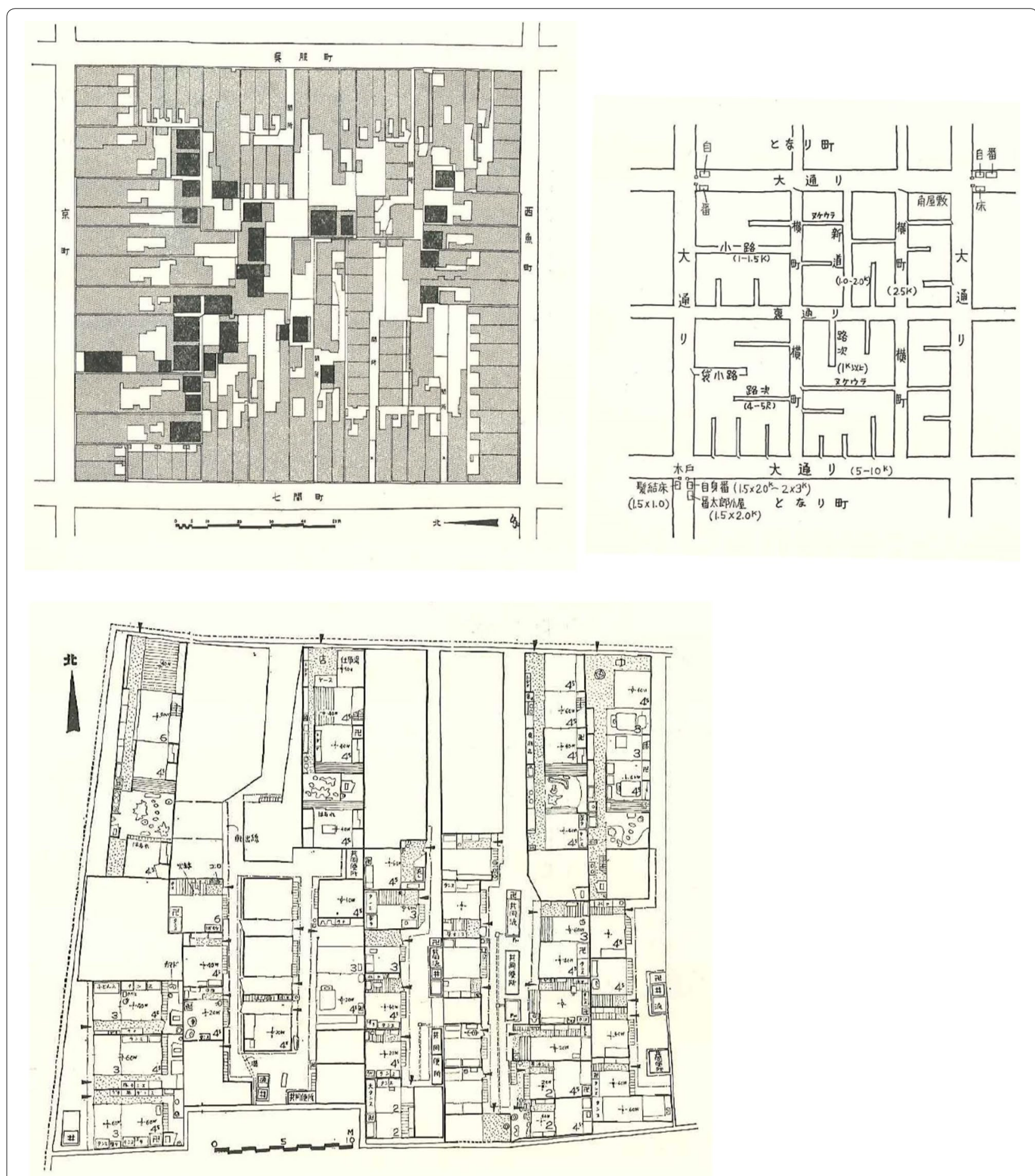

Fig. 3 (Left) Nagoya city blocks. The black colors are where the public toilets are located. (Right) Edo Nagaya (tenement houses) Map. Notice the backstreets or roji penetrating the blocks. (Bottom) Kyoto tenement houses and backstreets. Source: Nihon no Sumai (1975)

of human waste was a profitable sideline for slum landlords and there was little motivation to install expensive municipal sewage systems. The night soil collection system gradually declined in early twentieth century in central Tokyo with the construction of the sewerage system, but it survived until 1960s in the suburbs and other 
large cities where sewers were not built until the postwar period (Ishida 1994; Hanley 1997).

In Meiji period, houses had a dining-living room where the family gathered to eat, drink tea, and talk together which was called Chanoma, usually located near the kitchen on the northen side of the houses, but later in Taisho period we begin to find examples of south facing Chanoma. A town house with a south-facing chanoma was the final result of the modernization of the traditional Japanese style house. In the blocks where houses had east o west fronts, spaces from the neighboring buildings were provided to take advantage from the sun in the north or south side (Hirai 1998).

In Tokyo suburbs during the First World War, a type of dwelling emerged for the office workers called as Bunka Jutaku or cultural dwelling, typically with three or four little rooms, a kitchen and a bath. From early 1960s the 'mansion' age started, a foreign word put to a new use upon arriving in Japanese after a developer first used the word to designate his developments, which were condominiums in 1962. A mansion became any condominium, large or small, plain or extravagant (Seidensticker 2010).

\section{Preference in single-detached housing}

Almost universally held housing ideal of the detached single-family home set in a garden with a perimeter wall and symbolic entrance gate, which is frequently attributed to the desire to emulate the lost ideal of urban living represented by the spacious residential areas of samurai high city (Smith 1979; Jinnai 1994).

The housing ideal of the emerging middle class which grew notably in size after the First World War was modeled on the spacious detached houses of the samurai elite, and the detached house with a garden became the goal of all those who could afford it, since Meiji period. Sorensen (2004) stresses that this preference is thus of primarily domestic origins and is not an import from the Anglo-Saxon countries, although western suburban housing ideals have doubtless provided it strong support. This preference has had profound consequences for the development of the Japanese cities, particularly since the beginning of the suburbanization in the 1920s. By far the dominant form of owner-occupied housing is the detached single-family home as in Britain and North America, rather than the flatted block in continental Europe. In his book, Hirai (1998) describes when residents of high-density, multi-story city apartment houses are asked whether they wish to live there permanently, only about $10 \%$ say that they do, while between 50 and $70 \%$, depending on the estate, do not think of their present accommodation as a place to settle permanently. A separate survey found that $70 \%$ of people would choose to live in a detached house in the suburbs, albeit small and far from their workplace, rather than a convenient inner-city apartment block Hirai (1998).

In their studies about setbacks in Japan, researchers have proposed regulating building setbacks in relation to street lines to deal with lack of sunshine and ventilation in urban neighborhoods (Japanese Institute of Architecture 1996; Kuwata 1998). Gao and Asami (2001) have measured attributes such as FAR, building quality, proximity to public green spaces, having a parking space and sunshine duration for evaluating detached residential neighborhood pricing in the Tokyo area using a hedonic pricing model. They used the 1993 national housing survey of Japan, which stated that 32 percent of detached housing residents complained about a lack of sunshine and ventilation, and 36 percent felt that the surrounding buildings were unfavorable. As for developing the pricing model, there was a strong positive effect of being in front of a green public space. Hidano et al. (1998) evaluated building setback regulations in terms of the increase in the number of trees, followed by net benefit and cost for the individual household.

\section{Facades with no name-a study challenge}

The concept of facade is a new terminology in the Japanese architecture vocabulary. In many cases the word is imported and used in its original state in specialized texts. However for the Japanese people, facade refers to the 'surface of the wall'. Moreover, this surface of the wall is most of the time used when it refers to the street facades where the building's full surface is observed. Despite their very presence in the neighborhoods in Japan, side facades remain undermined and understudied. The first challenge for the authors therefore was how to name them in Japanese in order to ask the respondents about them afterwards. After multiple rounds of discussion with colleagues and asking various scholars from different backgrounds, the directly translated term 'side facades' was chosen and explained to the Sapporo respondents. As for the side setback areas, the term 'outdoor spaces' was used which referred to the spaces outside the side facades. However, for other regions of Japan the term Facade seemed to be an intangible and incomprehensible term. Therefore pictorial examples were used to describe what the authors mean by side facades and side setback areas in order to assure that the respondents do not confuse them with street facades (Fig. 4).

An online survey was chosen for this preliminary step of the research and promoted the survey among the architectural school's professors, lecturers and alumni at Hokkaido University Architectural Planning Laboratory. The link to the survey was sent to the prospective respondents by email and the data was collected through the website. Respondents from 59 cities in Japan filled 


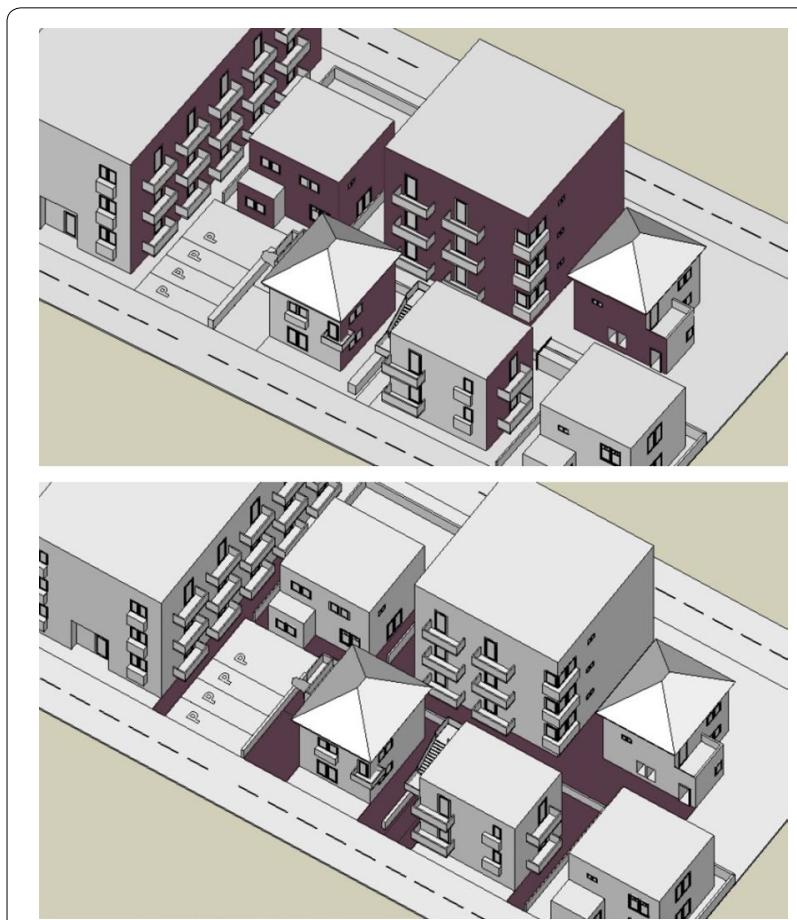

Fig. 4 Pictorial examples have been used to describe side facades and side setback areas in order to assure that the respondents do not confuse them with street facades

in the online questionnaire. This approach was in order to be as part of ongoing research; this is a step in which the general tendency and perceptions of respondents were studied and analyzed from all over Japan in order to present a general understanding of the concept of this research for further in-depth and local surveys.

The sample was obtained from respondents collectively from eight city planning categories around Sapporo. Two of these categories-Category 1 and 2 Low-rise Exclusive Residential-have a setback requirement of 1-1.5 meters between individual buildings. However, setbacks are present in the remaining categories in order to maintain the maximum floor area ratio.

\section{Relation between physical attributes of the neighborhoods and residents perception}

The relationship between people and their residential environment has been the subject of study for a significant number of research papers. A considerable amount of research has measured residential satisfaction given the fact that the neighborhood is a major contributor, sometimes equal to the home interior itself (Lawton 1982). Architectural features, proximity to green spaces, pollution, upkeep and maintenance and relationship with the neighbors have been emphasized as part of the importance of neighborhood context in residential satisfaction (e.g., Skjaeveland et al. 1996; Bonaiuto et al. 1999; Bonaiuto 2003; Apparicio 2006; Rioux et al. 2011). There are a large number of studies focusing on sense of community, neighborly interaction and neighborhood satisfaction. Social contact between neighbors has been found to be enhanced by the presence of three variables in the neighborhood: the opportunity for passive social contact, proximity to others, and appropriate space to interact (Festinger et al. 1950; Fleming et al. 1985).

In her research, Kaplan (2001) investigated residents' views from windows to the built environment and nearby nature as factors in their well-being and satisfaction. She found that the frequency of checking the sky from the windows played a small role in residents' sense of effective working and satisfaction. Views to the built environment that include other buildings, fences and walls played no significant role with respect to respondents' well-being compared to those who had views onto nature, except for cases involving neighboring busy streets, which had a negative effect on neighborhood satisfaction.

In a more physically relevant research, Yuan et al. (2012) studied building setbacks in dense urban environments for their influence on urban ventilation. Their results suggested that decreasing the site coverage ratio helps to increase natural ventilation on the pedestrian level. However the building setbacks are only more useful if they were designed along the prevailing wind direction rather than across it.

\section{Theoretical framework}

This research has a focus on side setback areas as opposed to front or backyards, assuming their capability of supporting any likely or desired activity which open spaces of similar types in front or back of the buildings normally provide for. Additionally, there is an assumption of whether these spaces contribute to the formation of neighborly ties between the neighbors mutually connected to them, via windows, terrace and balconies, etc. A set of relevant measures of the physical characteristics of the adjacent neighboring buildings was developed and put to test by demonstrating their relationship with the residents' activities (Skjaeveland et al. 1996); therefore, certain objective patterns of action such as the frequency of use of side setback areas for purposes such as looking outside, opening and closing windows, and the use of terrace/balconies onto side setback areas were questioned and then investigated.

This paper continues the previous conceptual framework while focusing on a physical aspect of the residential neighborhoods, the small-scale open spaces in the immediate periphery of residential buildings; in this case, side setbacks between adjacent buildings in the Japanese neighborhoods. Residents' perceptions and activities in 
side setback areas adjacent to the residential buildings have been measured by a multi-dimensional approach.

A pilot study of this research was carried out among architectural students at Hokkaido University in order to test the legibility of the concept and the questionnaire. A previous study on a similar topic, carried out as a self-reported questionnaire, was administered to 308 respondents voluntarily recruited from throughout Sapporo from September to December 2013.

There is an assumption here that there are links between attributes of the physical environment and the perceptions and activity of neighbors. A set of relevant measures of the physical characteristics of the adjacent neighboring buildings was developed. Few items on residential satisfaction were added in the margin of the survey in order to draw possible relationships between the views of the side setback areas and general residential satisfaction, namely quietness and sense of crowdedness in addition to the fact that one's interior is the first important factor for their satisfaction (Altman 1975; Apparicio 2006). This research therefore includes these items in its conceptual framework of residential satisfaction and perception assuming residential satisfaction for items such as aesthetics, safety, neighborhood sound and relations with the neighbors, following previous research.

The focus of this research is on the objective properties of side setback areas-physical elements of the residential buildings' facades-windows, terraces, and balconies etc.-as often very narrow distances, and on the view from one's window or balcony to the neighboring building. The approach is to examine the relation between placement of physical features of the neighboring buildings side facades, such as the location of windows or balconies etc. in relation to those on the adjacent side facade, and correlate them with the perceptions of individuals of such small open areas in terms of their privacy or intimacy, as their subjective meanings and whether they in any way contribute to the residents' satisfaction.

The demographic characteristics and living conditions of the respondents were then studied and analyzed as to whether they are predictors of activity and satisfaction which indicate respondents' perceptions of side setback areas and their physical environments in general. The physical and neighboring aspects of the side setback areas were measured both for respondents who had and did not have them by their houses and apartments.

\section{Research methods} Instrument: questionnaire

As a first step to establish the concept for the study, a self-reported questionnaire was designed and a copy of the URL address for the survey was sent to volunteers recruited from practicing architects or scholars from all around Japan. Respondents were asked to provide their location and area code in order to verify their location within the limits of the survey. One hundred and ninety respondents answered the questionnaire within the time limit. Later, answers from one respondent were discarded for being resident outside Japan and therefore not eligible for this study, and 14 responses were deleted from analysis for being incomplete (Fig. 5).

The previous stage of this study was carried out by starting with a pilot study among architectural students at Hokkaido University in order to test the legibility of the concept and the questionnaire.

Questionnaires were submitted to 190 respondents throughout Japan, from Hokkaido in the north to Kumamoto to the south of the country, from March to July 2014.

The first part of the questionnaire, activity, included questions pertaining to demographics and general characteristics of the respondents' buildings of residence. Sleeping and eating were hypothesized in this research to have taken place in Bedroom windows and kitchens. The respondents' postcodes were also requested in order to confirm their location within their city area and their city planning zones.

The investigation included a pictorial explanation of the concepts of the side setback areas and facades in order to clarify the aim and focus of the research, requiring the respondents to choose the facade which is not facing the street but rather faces the neighboring buildings (side facades).

The second part of the questionnaire included 77 items on respondents' perceptions of their residential space, based on five generic criteria: side setback areas, maintenance, neighbors, doors and windows to side setback areas and the side setback areas, including 12 items for preference and 15 items for neighboring relations. Eight items for general residential and neighborly satisfaction were included (Bonaiuto et al. 2003) to test the respondents' general tendency towards their neighborhood atmosphere and if it is influenced to any degree by their likely view to the neighboring building through the side setback areas. A Likert 5-point scale was used in which 1 means 'totally disagree' and 5 means 'totally agree'. All the respondents were asked to fill out this section of the questionnaire regardless of whether they actually have neighboring side setback areas, in order to examine general awareness about such side setback areas following Canter's notion of individuals conceptualizing spaces against actual 'users' (Canter 1986), as well as Stockols' evaluation of the quality of alternative places (Stockols and Shumaker 1981), which here would be an actual experience of place. 


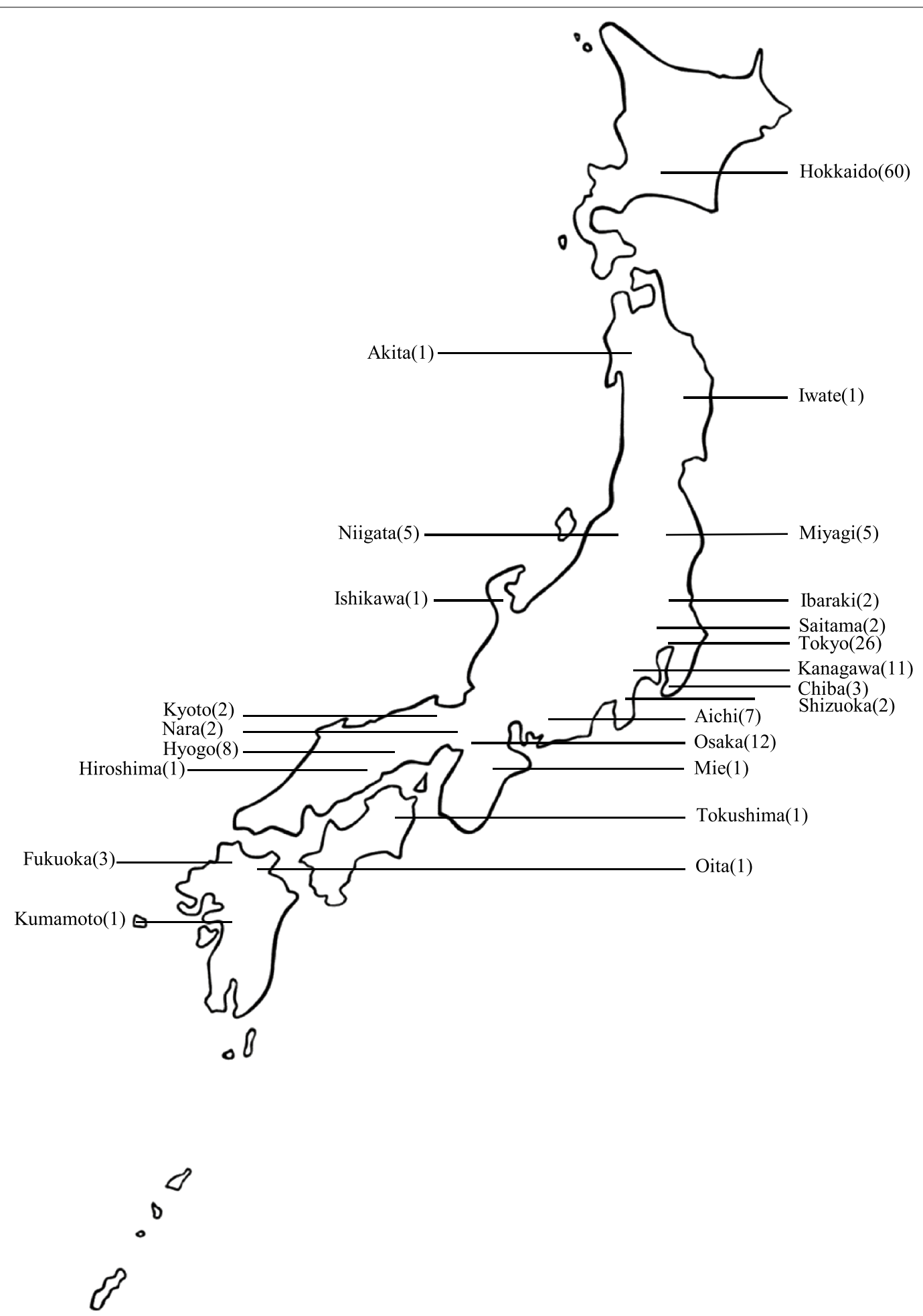

Fig. 5 Number of respondents and their location for the survey 


\section{Data analysis and discussion Descriptive statistics}

The respondents' demographic data for Japan shows diversity, with most of them being male $(\mathrm{n}=128)$ and being from various age groups; 20-29 (30); 30-39 (31); 40-49 (71); 50-59 (33); and 60 and older (19). One hundred and twenty were married and 63 were single. Most were working outside the home $(n=124)$. Seventy-six respondents were living in houses and 93 in apartments. (Eleven lived on the first floor; 25 on the 2nd floor; 14 on the 3rd floor; and 44 on the 4th floor and higher). Eightyfour were spending between 2 and 5 h every day at home, and 58 were spending between 5 and 10 h. 133 of the respondents reported that they had side facades mostly having their study rooms towards side setbacks followed by Bedroom windows. The physical properties of side setbacks suggested a good care, having access both physical and visual. Almost half the side setbacks from the sample were wide enough to accommodate car and be used as gardening activities, drying clothes and storage.

25 respondents stated that they have spaces for clothesdrying spaces, which suggests that these open spaces provide an ideal place to leave the clothes to dry. 39 respondents had poles for drying clothes fixed outside their windows to side setback areas (Table 1).

Analysis of Variance (ANOVA) was run on data based on the physical structure of the sample in order to investigate possible correlations between the presence of side setback areas and perceptions of the respondents. Twenty-five items were extracted from ANOVA where the perceptions and preferences were significantly correlated with the fact that the respondents either had or did not have a side setback area. The results are shown in Table 2. No demographic characteristic or housing type, floors or period of time living in the area were tapped to be significant in residents' perceptions towards the questionnaire items. The descriptive statistics of the items which were tapped are presented in Table 3. Comparing means showed that those who had no side setback area were more concerned with their privacy, smell, sound or darkness whereas those with side setback areas were more satisfied. As for preferences, having Green Wall, Terrace/Balcony and Living/Dining room windows were the preferred choices of those who had side setback areas, whereas having a Toilet window was the only choice for which those with no side setback areas, which can be explained after their previous perceptions for side setback areas as dark places where noise and smoke can easily travel and privacy is not respected.

Cronbach Alpha and KMO test results suggested insignificant internal consistency in both groups; therefore
Factor Analysis was skipped. For those perception items which were not tapped in ANOVA, data on the neighboring atmosphere and neighboring groups for all the respondents are shown in Table 4. Generally the data shows no significant notion and perception towards side setback areas and spaces looking onto them. $33 \%$ of the respondents believed that side setback areas are needed to keep the balance between built and open spaces. $27 \%$ denied the idea that they feel oppressed by looking at the nearby buildings from their windows onto side setback areas. Those items regarding neighboring presence and relationship mostly showed that having windows or terraces and balconies in close distances onto side setback areas did not provide neighbors with communication opportunities and that in general these areas are left out spaces with little presence of people.

For those items which were tapped after ANOVA a correlation tests reveals:

\section{Correlation test for those with side setback areas}

There are strong significant correlations between the subjective items 'Enough light comes from windows facing side setback areas' and 'Having ventilation from windows to side setback areas is enough, view is not important' (0.67, $\mathrm{p}=0.01$ ) and 'There is enough light' and 'There is good ventilation from windows to side setback area' $(0.66, \mathrm{p}=0.01)$. On the other hand, 'Having ventilation from windows to side setback areas is enough, view is not important' has a negative correlation with 'dark during the day' $(-0.52, \mathrm{p}=0.01)$.

'There is good air circulation in the side setback areas' has a fairly strong correlation with 'Having ventilation from windows to side setback areas is enough, view is not important' $(0.60, \mathrm{p}=0.01)$, and negative correlation with 'dark during the day' $(-0.50, \mathrm{p}=0.01)$.

The item 'There is good ventilation from windows to side setback area' has a negative correlation with 'I do not mind covering my side façade windows with goods, etc.' $(-0.50, \mathrm{p}=0.01)$.

These two items show that that side setback areas have subjectively good ventilation and sunlight reception; therefore respondents do no need to fill their windows or keep them closed. The fact that most of the respondents stated their houses and apartments has short-eave roofs testify the satisfactory sunlight reception into these narrow spaces (Fig. 6). In those cases where the predominance of large roof areas means that dwellings meet roof-to-roof the narrowness of the gaps between houses prevents airflow which can intensified by the exhaust from air conditioners and the use of dark-coloured roofs which absorb, rather than reflect, the heat (see Hall 2011). 


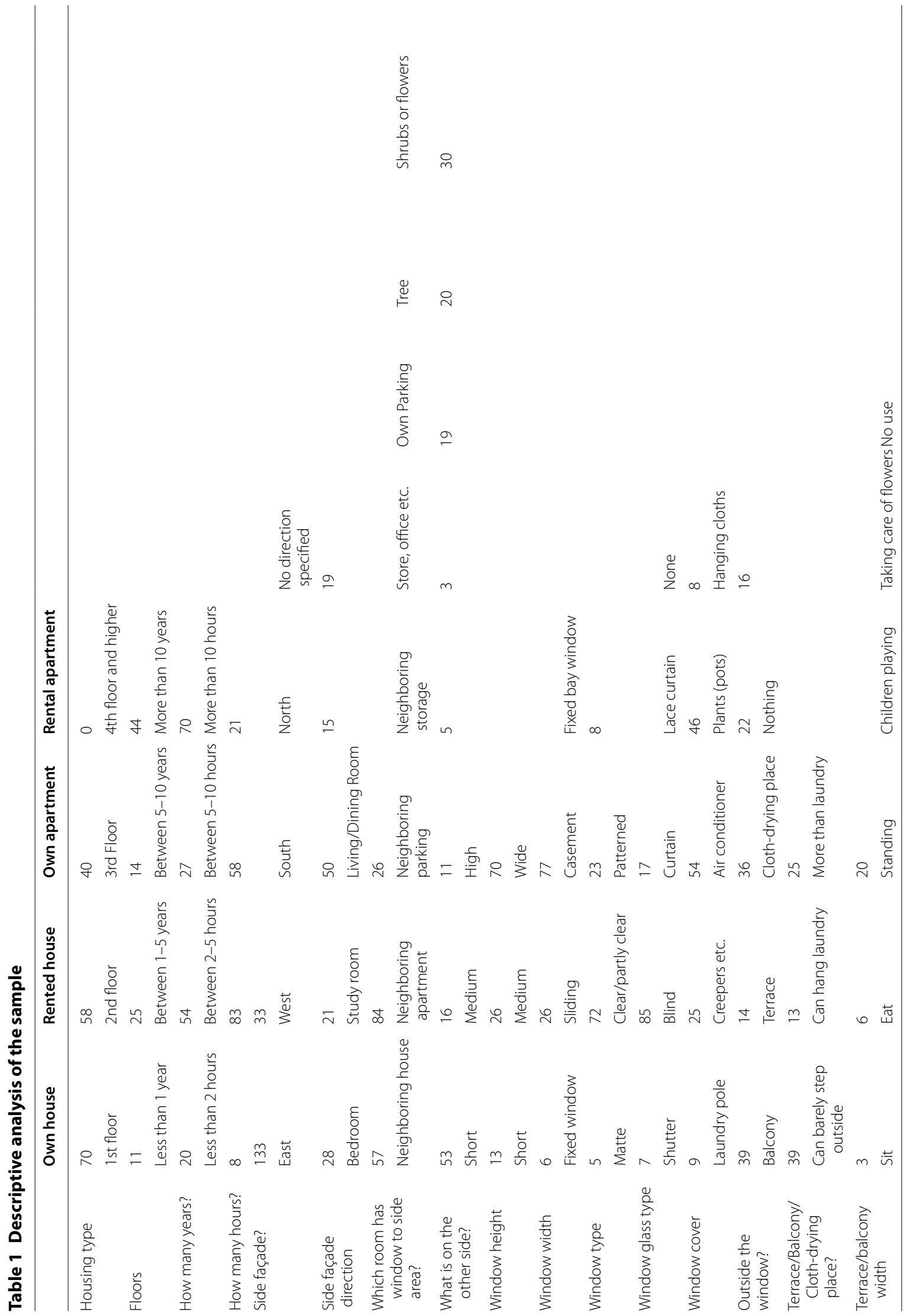




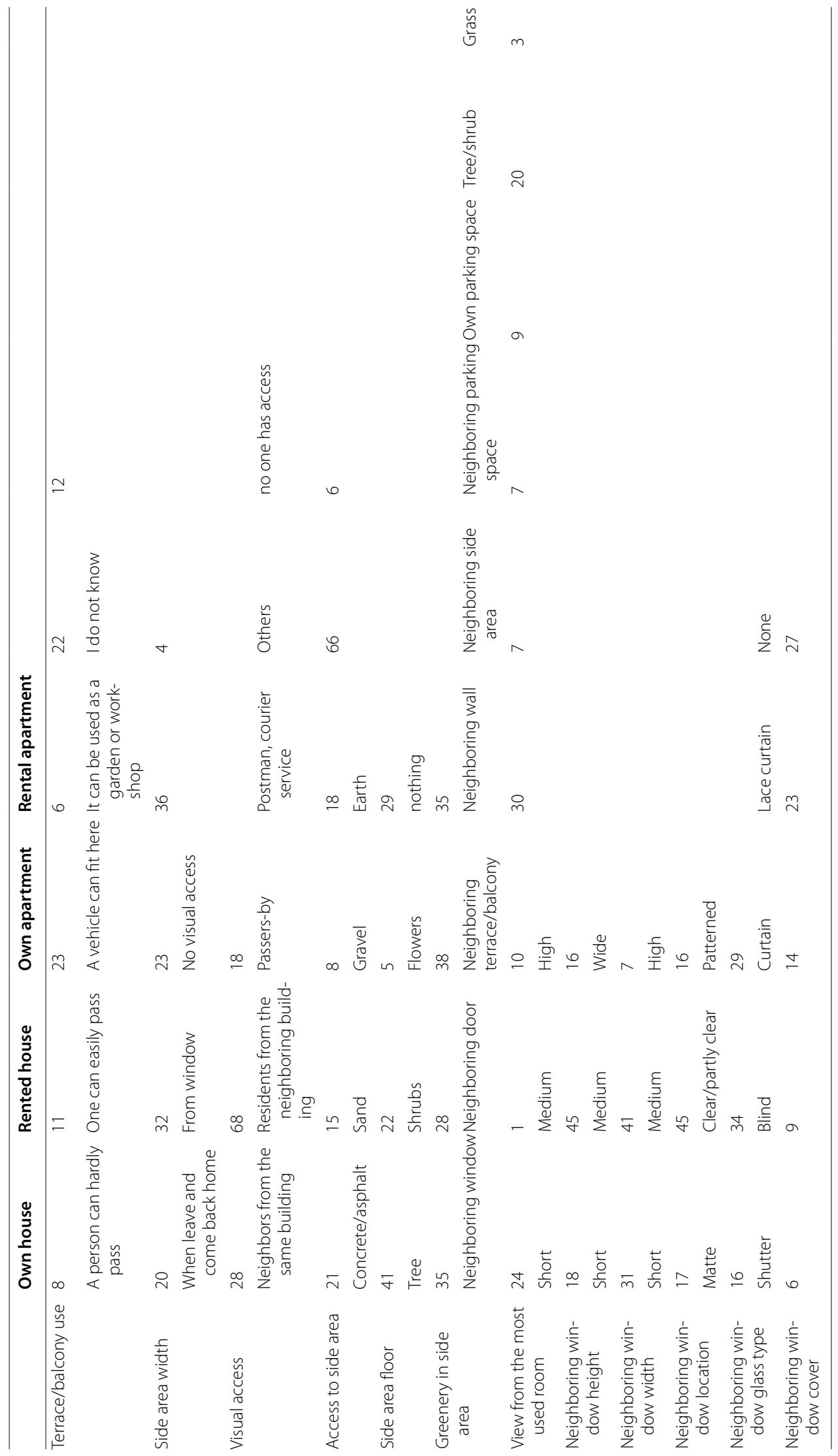


Table 2 ANOVA between respondents who had Side Setback areas and those who did not

\begin{tabular}{|c|c|c|}
\hline & $\mathbf{F}$ & Sig. \\
\hline Piping and wiring on neighboring side facades are done neatly & 4.03 & 0.01 \\
\hline Windows or balcony facing side setback areas are good for neighborhood intimacy & 4.25 & 0.01 \\
\hline Having windows facing side setback areas affects privacy & 8.15 & 0 \\
\hline Smells or smoke travel a lot through side setback areas & 8.38 & 0 \\
\hline There is good air circulation in the side setback areas & 4.2 & 0.01 \\
\hline I feel that I am being watched once inside setback areas or my terrace/balcony to them & 9.60 & 0 \\
\hline People do not interact with each other & 5.15 & 0.00 \\
\hline People have the habit of lending/borrowing & 7.65 & 0.00 \\
\hline Enough light comes from windows facing side setback areas & 7.18 & 0.00 \\
\hline There is good ventilation from windows to side setback area & 12.74 & 0 \\
\hline I do not mind covering my side facade windows with goods, etc. & 10.06 & 0 \\
\hline Prefer to see green wall from my window facing side setback area & 4.67 & 0.01 \\
\hline Prefer to see neighbor's clothes-drying place from my window facing side setback area & 3.10 & 0.04 \\
\hline Prefer to have living/dining room window facing side facade & 3.95 & 0.02 \\
\hline Prefer to have bathroom/toilet window facing side setback area & 5.22 & 0.00 \\
\hline Prefer to have terrace/balcony facing side setback area & 2.39 & 0.09 \\
\hline Side setback areas are dark even during the day & 5.40 & 0.00 \\
\hline There is a calm atmosphere in side setback areas away from the street & 4.24 & 0.01 \\
\hline Having ventilation from windows to side setback areas is enough, view is not important & 10.47 & 0 \\
\hline Windows to side setback areas should have matte glass & 5.89 & 0.00 \\
\hline This is an ideal neighborhood for me & 4.85 & 0.00 \\
\hline Security is good here & 3.28 & 0.04 \\
\hline People respect privacy & 3.55 & 0.03 \\
\hline I have a quiet life here & 8.02 & 0 \\
\hline Life is pleasant here & 6.01 & 0.003 \\
\hline
\end{tabular}

Subjective items on neighborhood atmosphere also have a good correlation. The item 'I have a quiet life here' has a strong correlation with 'This is an ideal neighborhood for me' $(0.63, \mathrm{p}=0.01)$, 'Security is good around here' $(0.63, \mathrm{p}=0.01)$ (Table 5).

In Summary, data analysis suggests the respondents' satisfaction with the light and ventilation coming from side setback areas. The descriptive statistics show that a vast majority of the windows were operable with clear glasses despite the fact that these windows look onto the, in many cases, neighboring wall or window.

\section{Correlation Test for those with no Side setback areas}

Unlike the results for those who had side setback areas, there are relatively strong correlations between the subjective items and preferences of having spaces by side setback areas for those respondents who had no side setback areas. Preferences for having neighbor's clothes-drying space and one's Living/Dining room windows were notably correlated $(0.52, \mathrm{p}=0.01)$, Living/Dining room windows and Terrace/balcony $(0.56, \mathrm{p}=0.01)$.
Having one's Living/Dining room windows looking onto side setback areas was negatively correlated with the item 'Should have matte glass' $(-0.63, \mathrm{p}=0.01)$, which means the respondents did not necessarily prefer to have matte glass windows onto side setback areas for all their living spaces, indicating that they were not concerned about their privacy. Having Toilet window to side setback areas was negatively correlated with 'Having ventilation from windows to side setback areas is enough, view is not important' $(-0.55, \mathrm{p}=0.01)$ which is questionable.

The preference for having Terrace/balcony was positively correlated with 'Good atmosphere away from the street' $(0.56, \mathrm{p}=0.01)$. 'Enough light comes from windows facing side setback areas' was positively associated with 'There is good ventilation from windows to side setback area' $(0.69, \mathrm{p}=0.01)$.

Of the subjective items, the item 'I feel that I am being watched' has a strong negative correlation with 'People do not interact with each other' $(-0.75, \mathrm{p}=0.01)$, which suggests the respondents' anticipation for more neighborly contact within neighborhoods with side setback 
Table 3 Descriptive statistics of the items tapped in ANOVA

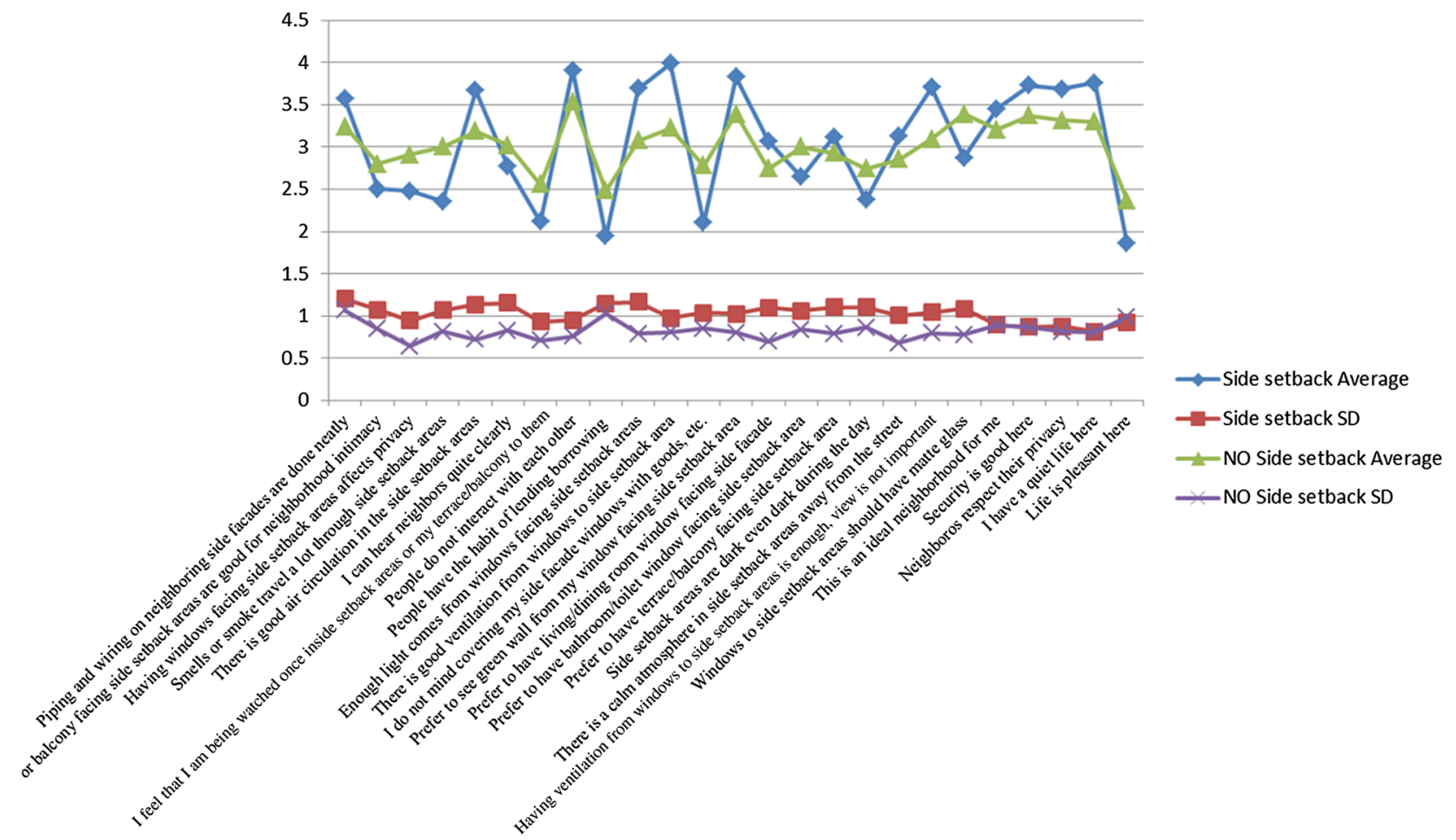

areas. 'I feel that I am being watched' and 'People respect privacy' were negatively correlated $(-0.65, \mathrm{p}=0.01)$, which suggests a concern with privacy. So do the items 'Having windows facing side setback areas affect privacy' and 'Having ventilation from windows to side setback areas is enough, view is not important' $(-0.69, \mathrm{p}=0.01)$, plus the fact that respondents anticipate more from the windows than only light or ventilation.

In support of the above assumption, the item 'People do not interact' was correlated with the preference of having a Green wall $(0.65, \mathrm{p}=0.01)$. 'I prefer to look at neighbor's clothes-drying space' was correlated with 'I feel that I am being watched' $(0.60, \mathrm{p}=0.01)$, which further proves that the respondents preferred the neighboring building to have a clothes-drying space as a threshold which is believed to be less frequently used than terraces and balconies, so that their privacy is protected.

There are very high correlations with the subjective items about neighborhood atmosphere Table 6).

The results for the correlation matrix for both groups -those who had side setback areas, and, those who did not have side setback areas- showed a general tendency towards perceiving the side setback areas as possible threats to one's privacy for those who did not have them. This is in contrast to those respondents who had side setback areas, who did not perceive these spaces as a threat to their privacy, but rather enjoyed the amount of light and air circulation they receive from there, more than the likely view.

\section{Conclusion}

The present paper challenges further thinking and research on the characteristics of small open spaces surrounding buildings in the residential environments and how these seemingly insignificant spaces contribute to the lives or neighborhood perceptions of their residents.

The perception of side setback areas and building facades abutting them are yet to be established for the residents. There is a very little impression on these environments and they are seen only as mere left out spaces between the building and the boundaries. No significant impact on the respondents' perceptions on neighboring was demonstrated by either having or not having windows or terrace/balconies to side setback areas.

On the subject of usage of the side setback areas, the presence of neighbors such as children or elderly persons and activities such as gardening was noted, as these places were seen as not abandoned spaces but subject to considerable maintenance, and were suggested by a significant number of the respondents as good places for parking places, storing items and drying clothes. The preference for having neighboring terrace/balcony or 
Table 4 Descriptive statistics of the items not tapped in ANOVA

\begin{tabular}{|c|c|c|c|c|c|}
\hline & Totally agree (\%) & Agree (\%) & No idea (\%) & Disagree (\%) & $\begin{array}{l}\text { Totally disa- } \\
\text { gree (\%) }\end{array}$ \\
\hline $\begin{array}{l}\text { I feel oppressed seeing buildings so close from the window facing } \\
\text { the side setback area }\end{array}$ & 11 & 15 & 34 & 12 & 27 \\
\hline $\begin{array}{l}\text { Side setback areas are needed for balance between built and open } \\
\text { spaces }\end{array}$ & 33 & 20 & 36 & 3 & 5 \\
\hline There is sufficiently large setback between adjacent buildings & 11 & 17 & 42 & 17 & 12 \\
\hline Stored items in side setback areas are kept clean & 21 & 24 & 40 & 8 & 6 \\
\hline Side setback areas are abandoned places & 7 & 18 & 41 & 14 & 19 \\
\hline Side setback areas are used as storage only & 3 & 10 & 46 & 17 & 24 \\
\hline $\begin{array}{l}\text { If large windows face side setback areas, it will be more observed } \\
\text { and clean }\end{array}$ & 10 & 20 & 51 & 10 & 9 \\
\hline There are decorations on the windows facing side facades & 6 & 11 & 46 & 14 & 23 \\
\hline There is enough greenery in the neighborhood & 8 & 19 & 51 & 12 & 9 \\
\hline More greenery is needed in this neighborhood & 16 & 24 & 50 & 6 & 4 \\
\hline Having windows to side setback areas makes the room look bigger & 19 & 17 & 51 & 6 & 6 \\
\hline The view from my side window is not good & 6 & 9 & 52 & 18 & 15 \\
\hline Side setback areas should have fences & 7 & 10 & 50 & 17 & 14 \\
\hline Neighbors take care of flowers or lawn in their side setback area & 12 & 16 & 44 & 12 & 16 \\
\hline Neighbors do gardening in their side setback areas & 15 & 14 & 42 & 13 & 16 \\
\hline $\begin{array}{l}\text { I do not look at neighbors window or terrace when I am in the side } \\
\text { setback area }\end{array}$ & 29 & 27 & 37 & 2 & 3 \\
\hline $\begin{array}{l}\text { I try not to be seen when I am behind the window or at the balcony } \\
\text { facing side setback areas }\end{array}$ & 17 & 20 & 45 & 11 & 6 \\
\hline $\begin{array}{l}\text { I pay attention to the surroundings when I open or close my win- } \\
\text { dow facing side setback area }\end{array}$ & 13 & 21 & 43 & 13 & 7 \\
\hline I can hear neighbors quite well from side setback area & 8 & 12 & 47 & 19 & 13 \\
\hline Presence of strangers is a problem here & 6 & 19 & 50 & 14 & 11 \\
\hline Neighbors are interested in neighboring relations & 5 & 16 & 51 & 16 & 12 \\
\hline Neighbors tend to be isolated & 3 & 5 & 55 & 18 & 19 \\
\hline Neighbors do not tolerate noise & 1 & 2 & 52 & 24 & 21 \\
\hline Neighbors have mutual interest & 4 & 6 & 56 & 14 & 19 \\
\hline I keep relations with my neighbors only on the surface & 23 & 22 & 42 & 5 & 6 \\
\hline Neighbors support each other & 9 & 11 & 41 & 10 & 28 \\
\hline Neighbors help each other with shopping etc. & 2 & 5 & 39 & 9 & 45 \\
\hline Neighbors interact & 2 & 2 & 35 & 8 & 52 \\
\hline I know my neighbors by name & 27 & 14 & 32 & 4 & 22 \\
\hline I have a chance to talk to my neighbors & 8 & 11 & 35 & 6 & 39 \\
\hline I keep contact through window or terrace to side setback areas & 3 & 5 & 39 & 14 & 39 \\
\hline Children play in side setback areas & 10 & 9 & 41 & 6 & 34 \\
\hline Elderly walk around side setback areas & 3 & 6 & 41 & 6 & 43 \\
\hline Postmen or construction workers come here & 5 & 7 & 40 & 7 & 40 \\
\hline $\begin{array}{l}\text { Prefer to see neighbor's wall from my window facing side setback } \\
\text { area }\end{array}$ & 13 & 14 & 51 & 11 & 10 \\
\hline $\begin{array}{l}\text { Prefer to see neighbor's small window from my window facing side } \\
\text { setback area }\end{array}$ & 7 & 14 & 50 & 16 & 12 \\
\hline $\begin{array}{l}\text { Prefer to see neighbor's large window from my window facing side } \\
\text { setback area }\end{array}$ & 5 & 7 & 47 & 19 & 20 \\
\hline $\begin{array}{l}\text { Prefer to see neighbor's terrace/balcony from my window facing } \\
\text { side setback area }\end{array}$ & 6 & 13 & 47 & 19 & 13 \\
\hline Prefer to have bedroom window facing side setback area & 4 & 9 & 52 & 14 & 18 \\
\hline Prefer to have kitchen window facing side setback area & 7 & 17 & 59 & 9 & 6 \\
\hline Prefer to have clothes-drying place facing side setback area & 7 & 16 & 56 & 10 & 10 \\
\hline
\end{tabular}


Table 4 continued

\begin{tabular}{|c|c|c|c|c|c|}
\hline & Totally agree (\%) & Agree (\%) & No idea (\%) & Disagree (\%) & $\begin{array}{l}\text { Totally disa- } \\
\text { gree (\%) }\end{array}$ \\
\hline Side setback areas make residences cold during winter & 5 & 9 & 49 & 14 & 23 \\
\hline Side setback areas are good for storing bicycles etc. & 7 & 18 & 49 & 11 & 14 \\
\hline Good for having clothes-drying place & 10 & 15 & 49 & 7 & 18 \\
\hline Side setback areas are good for storing big items & 3 & 12 & 52 & 11 & 21 \\
\hline Side setback areas are good for storage purposes & 4 & 16 & 57 & 9 & 13 \\
\hline Side setback areas are good for storing bicycles etc. & 8 & 20 & 50 & 5 & 16 \\
\hline Side setback areas are good for parking places & 7 & 14 & 52 & 7 & 19 \\
\hline Side setback areas are good for gardening & 11 & 19 & 46 & 12 & 11 \\
\hline Side setback areas are good for drying clothes & 5 & 17 & 47 & 13 & 18 \\
\hline This is a pleasant neighborhood & 11 & 20 & 42 & 17 & 9 \\
\hline This neighborhood is too crowded & 2 & 8 & 41 & 27 & 20 \\
\hline I cannot say this neighborhood is quiet & 7 & 10 & 42 & 19 & 22 \\
\hline
\end{tabular}

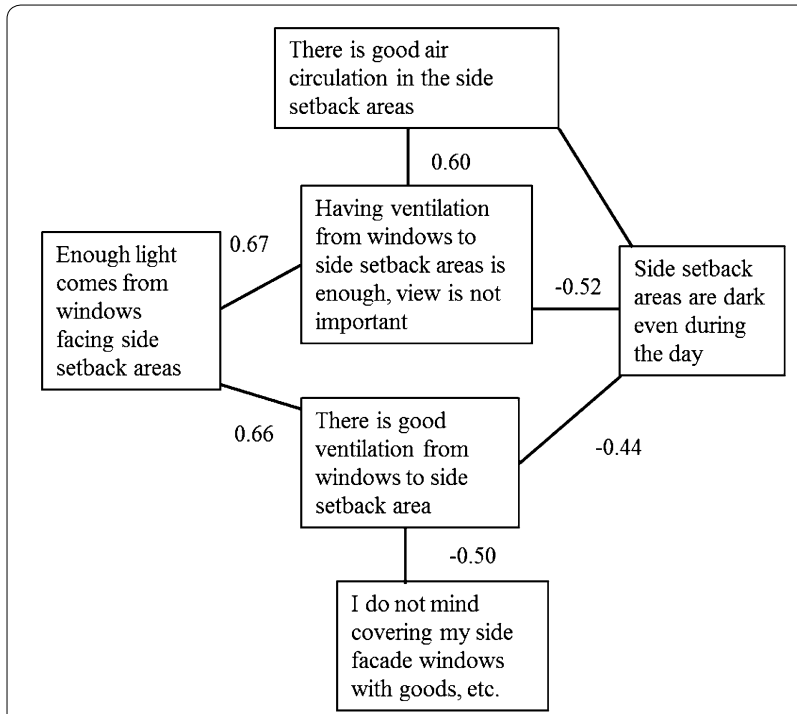

Fig. 6 Correlation path for subjective items on sunlight and air quality of side setback areas for those respondents who had side setbacks large window suggested that there was no concern from both groups for privacy.

Numerous design suggestions can be drawn from side setbacks in Japanese cities case, in terms of their capability for providing better ventilation, landscaping and parking spaces as shown in Fig. 7. However, the idea of utilization of side setbacks and is yet to be challenged. The usage of these spaces is practiced on individual basis mainly including storage and small scale gardening purposes, with little intervention by professional designs which can be summarized to: opening toilet windows with matte glasses to provide them with ventilation; placing the windows not directly opposite the existing neighboring façade; having similar façade material to street façade; and, designing short-eave roofs to allow sunlight in. In this preliminary report, there was no interest from the respondents' side in developing any social contact with the adjacent neighbors amid their very close arrangement. However, when privacy is desired, the Japanese example shows a desirable prototype. 


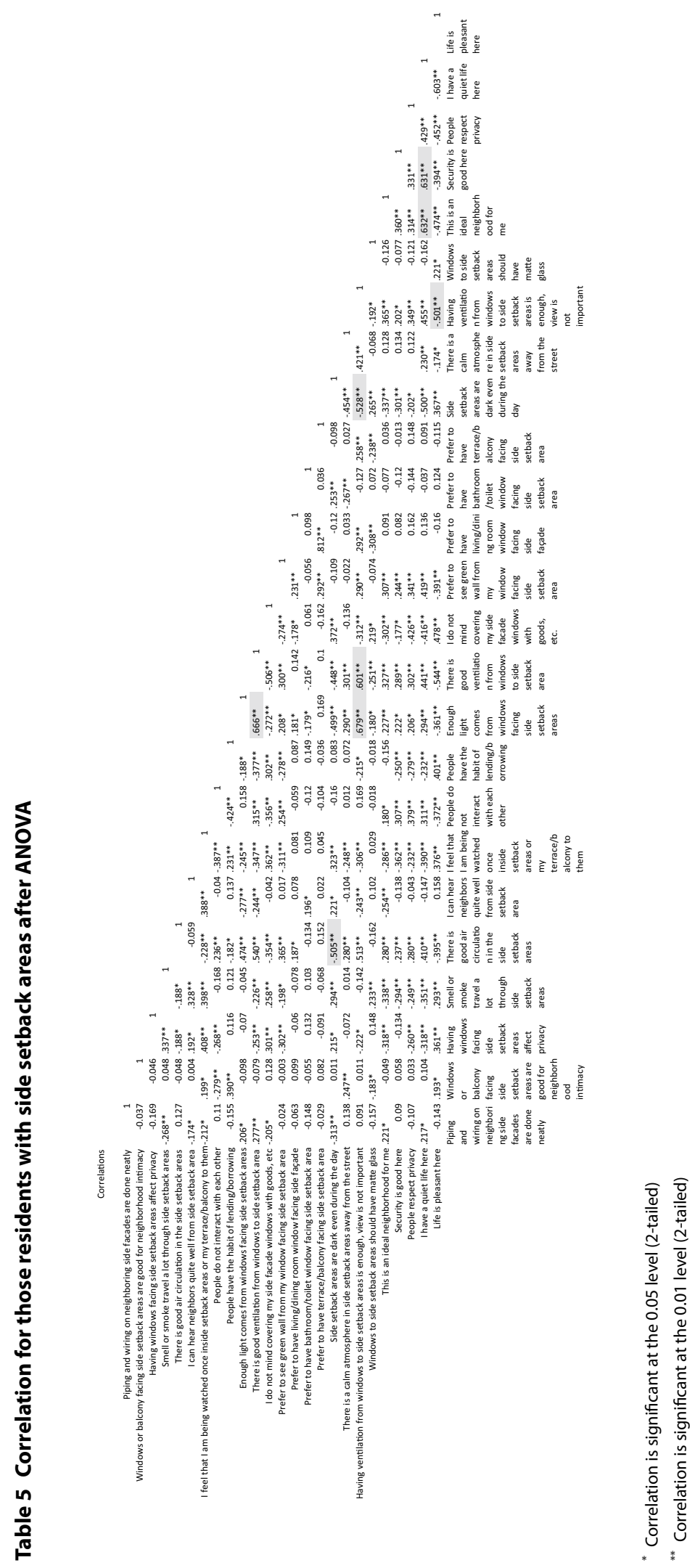




\begin{tabular}{|c|c|}
\hline $\begin{array}{l}\text { SIDE YARDS } \\
\text { Wider side setback areas can } \\
\text { provide for additional } \\
\text { household functions as drying } \\
\text { of clothes, gardening and } \\
\text { household workshop related } \\
\text { activities, provided that flat } \\
\text { roofs or short hanging eaves } \\
\text { ensure their enough sunlight } \\
\text { reception. } \\
\text { Pictures: Sapporo }\end{array}$ & 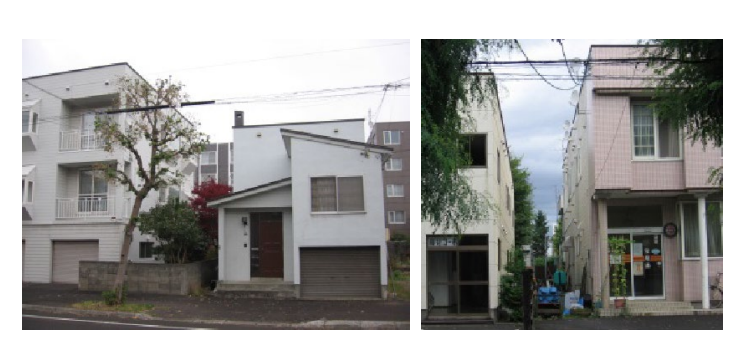 \\
\hline $\begin{array}{l}\text { PARKING SPACES } \\
\text { In cases of apartments, side } \\
\text { setbacks provide parking } \\
\text { spaces for cars or bicycles, with } \\
\text { added visual access and control } \\
\text { to the street from more } \\
\text { apartment units. } \\
\text { Left: Sapporo }\end{array}$ & 四 \\
\hline $\begin{array}{l}\text { CROSS VENTILATION } \\
\text { Side setbacks provide for better } \\
\text { cross ventilation. Air vents are } \\
\text { placed on the side walls for } \\
\text { each room and apartment unit. } \\
\text { This saves collecting } \\
\text { ventilation pipes to the roofs. } \\
\text { Left: Sapporo } \\
\text { Right: Kita-Hiroshima }\end{array}$ & +5 \\
\hline $\begin{array}{l}\text { SECONDARY STORAGE } \\
\text { Side setbacks can } \\
\text { accommodate instrumental } \\
\text { functions ranging from storage } \\
\text { (gas tanks, air conditioners, } \\
\text { gardening etc.) and utility } \\
\text { purposes (piping outlets, vents, } \\
\text { gas and electricity meters etc.). } \\
\text { Left: Kurashiki } \\
\text { Right: Sapporo }\end{array}$ & 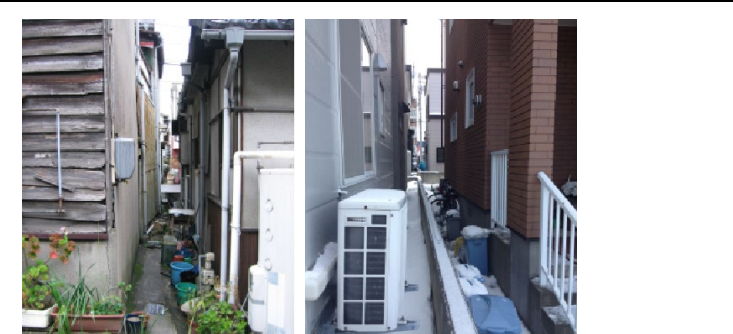 \\
\hline
\end{tabular}

Fig. 7 Design Implications for side setbacks citing ordinary utilization of these spaces

Further studies are needed on more consistent ways and focused on specifies localities in order to draw comparisons between the geographical and demographical distinctions or different urban environments.

\section{Authors' contributions}

The concept of this research was developed by AS. AS carried out the survey and drafted the manuscript. SM and RN made substantial contribution to designing the survey, acquiring necessary permissions and recruiting respondents. SM and RN contributed in the revision of the manuscript for its intellectual context. All authors read and approved the final manuscript.

\section{Competing interests}

The authors declare that they have no competing interests.
Received: 13 July 2015 Accepted: 26 April 2016

Published online: 07 June 2016

\section{References}

Altman I (1975) The environment and social behavior. Brooks/Cole Publishing Company, Monterery CA

Apparicio P, Seguin AM (2006) Measuring the accessibility of services and facilities for residents of public housing in montreal. Urban Studies 43(1):187-211

Ashihara Y (1986) The hidden order: toward the city of the 21st century. Chuokoronsha, Tokyo

Bonaiuto M, Aiello A, Perugini M, Bonnes M, Ercolani AP (1999) Multidimensional Perception of Residential Environment Quality and Neighboring Attachment in the Urban Environment. J Environ Psychol 19(4):331-352 
Bonaiuto M, Fornara F, Bonnes M (2003) Indexes of perceived residential environment quality and neighborhood attachment in urban environments: a confirmation study on the city of Rome. Landsc Urban Plann 65:41-52

Canter D (1986) Putting situations in their place: foundations for a bridge between social and environmental psychology. In: Furnham A (ed) Social behavior in context. Allyn and Bacon, London, pp 208-239

Evans GW, McCoy JM (1998) When buildings don't work: The role of Architecture in human health. J Environ Psychol 18:85-94

Festinger L, Schachter S, Back K (1950) Social Pressure informal groups. Holt Rinehart \&Winston, New York

Fleming R, Baum A, Singer JE (1985) Social support and the physical environment. In: Cohen S, Syme SL (eds) Social support and health. Academic Press, Orlando

Gao X, Asami Y (2001) The external effects of local attributes on living environment in detached residential blocks in Tokyo. Urban Studies 38(3):487-505

Habraken NJ, Teicher J (2000) The structure of the ordinary: form and control in the built environment. MIT Press, Cambridge

Hall A (2011) Design, not density of urban forms as the path to sustainability: an examination of examples urban green space provision in relation to density. NSW: State of Australian Cities Conference 2011 Proceedings

Hanley S (1997) Everyday things in premodern Japan: The hidden legacy of material culture. University of California Press, Berkeley

Hidano N, Kameda M, Ando S (1998) Studies on the benefit and cost of a setback regulation. Proc Jpn Real Estate Instit 12:125-128

Hirai K (1998) The Japanese house then and now, Translated by Marie Jelinek. pp. 73-115. Ichigaya Publications: Tokyo

Ishida Y (1994) 'Agricultural Land Use in the Urbanized Area of Tokyo: History of Urban Agriculture in Tokyo', Paper presented on the 6th International Planning History Society, Hong Kong

Jinnai H (1994) 'Tokyo, a Model for the 21st Century?' Paper presented to the European Association of Japanese Studies Conference, August 1994

Japanese Institute of Architecture, Special Committee on Urban Housing Research (1996) Basic terms or urban housing and housing land. Japanese Institute of Architecture, Tokyo

Kaplan R (2001) The nature of the view from home: psychological benefits. Environ Behav 33(4):507-542
Kento Yoshida, Essays in Idleness, The Tsurezuregusa of Kento (1330-1332), Translated by Donald Keene (1981) Tuttle Publishing: Tokyo

Kuwata H (1998) A Study of building control for sunlight preservation in blocks. Papers on City Planning 33:787-792

Lawton MP (1982) Competence, environmental press, and the adaptation of older people. In: Lawton MP, Windley PG, Byerts TO (eds.) Aging and the environment: Theoretical approaches. pp. 33-59. Springer: New York

Lynch K (1960) The image of the City. MIT Press, Cambridge, Massachusetts Morse Edward S (1972) Japanese houses and their surroundings. C.E. Tuttle, Tokyo

Rioux L, Werner C (2011) Residential satisfaction among aging people living in place. J Environ Psychol 31(2):158-169

Seidensticker E (2010) Tokyo from Edo to Showa 1867-1989, the emergence of the world's greatest city. Singapore, Tuttle Publishing, Singapore

Shelton B (1999) Learning from the Japanese City. Routledge, New York

Skjaeveland O, Garling T, Maeland JG (1996) A multidimensional measure of neighbouring. Am J Community Psychol 24:413-435

Smith HD (1979) 'Tokyo and London: comparative conception of the City' in Japan: Comparative view, Craig AM (Ed). Princeton University Press: Princeton, NJ

Sorensen A (2004) The making of urban Japan_cities and planning from edo to the twenty-first century. Routledge, London

Stockols D, Shumaker SA (1981) In: Harvey J (Ed), Cognition, social behavior, and the environment. pp. 441-488. Lawrence Erlbaum: Hillside NJ

The Building Standard Law of Japan on CD-ROM (May 2009) The building centre of Japan: Tokyo

Wada Y (2007) Reading the French landscape: contemporary urban planning on regulation and preservation. Kashima Publishing Co, Tokyo

Weisman G (2001) The place of people in architectural design. In: Pressman A (ed) The architect's portable design handbook: a guide to best practices. McGraw Hill, New York

Yuan C, Ng E (2012) Building porosity for better urban ventilation in high-density cities-a computational parametric study. Build Environ 50:176-189

\section{Submit your manuscript to a SpringerOpen ${ }^{\circ}$ journal and benefit from:}

- Convenient online submission

- Rigorous peer review

- Immediate publication on acceptance

- Open access: articles freely available online

- High visibility within the field

- Retaining the copyright to your article

Submit your next manuscript at springeropen.com 